\title{
ILCEA
}

Revue de l'Institut des langues et cultures

d'Europe, Amérique, Afrique, Asie et Australie

39 | 2020

Les humanités numériques dans une perspective internationale : opportunités, défis, outils et méthodes

\section{A Holistic Approach for Measuring Quality of Life in "La Condesa" Neighbourhood in Mexico City}

Une approche holistique pour mesurer la qualité de vie dans le quartier de «La Condesa » à Mexico

Un enfoque holístico para medir la calidad de vida en el barrio "La Condesa" en

la Ciudad de México

\section{Genoveva Vargas Solar and Ana-Sagrario Castillo-Camporro}

\section{CpenEdition}

\section{Journals}

Electronic version

URL: http://journals.openedition.org/ilcea/10063

DOI: 10.4000/ilcea.10063

ISSN: 2101-0609

\section{Publisher}

UGA Éditions/Université Grenoble Alpes

Printed version

ISBN: 978-2-37747-174-4

ISSN: 1639-6073

\section{Electronic reference}

Genoveva Vargas Solar and Ana-Sagrario Castillo-Camporro, «A Holistic Approach for Measuring

Quality of Life in "La Condesa" Neighbourhood in Mexico City », ILCEA [Online], 39 | 2020, Online since 03 March 2020, connection on 10 October 2020. URL : http://journals.openedition.org/ilcea/10063 ; DOI : https://doi.org/10.4000/ilcea.10063

This text was automatically generated on 10 October 2020

(C) ILCEA 


\section{A Holistic Approach for Measuring Quality of Life in "La Condesa" Neighbourhood in Mexico City}

Une approche holistique pour mesurer la qualité de vie dans le quartier de « La Condesa » à Mexico

Un enfoque holístico para medir la calidad de vida en el barrio "La Condesa" en la Ciudad de México

Genoveva Vargas Solar and Ana-Sagrario Castillo-Camporro

\section{Context and motivation}

1 Urban territories are complex living systems where citizens organize their daily life by interacting with the built environment and urban infrastructure. Disciplines such as urban planning and urban sociology focus on the physical design and management of urban structures and on the urban life and culture. The emergence of urbanism and its disciplines has called architects, planners, geographers, and sociologists, and lately data scientists to investigate the way people live and feel in densely populated urban territories. Sociologic, psychologic, medical and economic studies believe that "quality of life and its four domains (physical health, psychological health, social relationships and environment) are significant predictors of subjective wellbeing and also to examine the quality of life in terms of gender, socio-economic level, the number of sibling, living environment, mother education level and father education level"3.

2 According to World Health Organization (WHO), quality of life (QoL) is defined as "an individuals' perception of her position in life in the context of the culture and value systems in which she lives, and in relation to her goals, expectations, standards and concerns"'. Costanza et al. ${ }^{5}$ consider that people evaluate their QoL according to how they perceive satisfaction or dissatisfaction in various life domains. Thus, people subjectively asses their life and in consequence their wellbeing perception by 
comparison. Studies like Malkoç (2011) put forward and validate the hypothesis that QoL and its domains can be used as predictors of subjective wellbeing. Even if these studies have been performed in micro-cosmos like university campi, we believe that similar methodologies can be applied in urban territories. That is, urban planning strategies implemented to improve urban territories in terms of economy, infrastructure, services and built environment, can rely on QoL measures to determine how they impact the perception of wellbeing in citizens evolving in those territories.

The literature refers to Mathematical models for measuring QoL index ${ }^{6}$. Some consider measurable variables often based on economic indices ${ }^{7}$. Others consider qualitative variables such as happiness, noise and stress ${ }^{8}$. Other visions like the theory of utilitarianism by Jeremy Bentham define QoL index as the maximum wellbeing that can be experienced by the maximum number of people. This goes beyond the measurement of an index, which means computing a value, but it seeks to define a point within a spectrum where economic and wellbeing benefits are optimised.

4 The "intelligent" and virtuous design of urban territories as living environments is often planned considering a one variable optimisation objective for example and mainly economy activation. When urban planning strategies are applied to activate the economy in urban territories, computing the quality of life index (QoL index) can be an adapted assessment strategy. QoL index can of course be interpreted in simple terms, for example in terms spending power increase, yet this is too simplistic. In fact, this index is defined as a "multidimensional index measuring good living conditions and degree of 'wellbeing'. It includes the collective satisfaction of needs obtained through social and public policies"9. According to (Stiglitz, Sen \& Fitoussi, 2009), "research has shown that it is possible to collect meaningful and reliable data on subjective, as well as objective wellbeing. Subjective wellbeing encompasses different aspects (cognitive evaluations of one's life, happiness, satisfaction, positive emotions such as joy and pride, and negative emotions such as pain and worry): each of them should be measured separately, to derive a more comprehensive appreciation of people's lives". Thus, our work combines different groups of variables to compute the QoL index under different perspectives. Instead of providing just one Mathematical model for combining variables that can intervene in the evaluation of QoL index we provide different perspectives of it, by computing several values relying on different Mathematical models for computing this index. Having different Mathematical models for the QoL index of an urban territory leads to what we call an "holistic" evaluation of QoL. All perspectives are complementary and say much more about the QoL of an urban space than each of them, that is, as stated by holism principles, "the whole is greater than the sum of its parts".

5 According to utilitarianism, urban territories improvement strategies must generate the highest benefit to the maximum number of people. Still, this is a static vision of the way changes performed in urban territories in a given period of time have side effects on the experience of citizens as "users" of these territories. Perception about urban territories can be seen as a spectrum determined by different social, economic, psychological variables. Our work introduces the concept of "elasticity of quality of life" (E-QoL) that defines a relationship between the QoL of the inhabitants in a territory with respect to variables affecting inhabitants' welfare. E-QoL goes beyond computing an index, it rather finds a point where economic and immaterial benefits obtained through the implementation urban planning strategies are optimised. Thus, 
E-QoL maximises a holistic return of investment that considers quantitative (e.g., income) and qualitative (e.g., perception of security, satisfaction, self-assessment) variables calibrated to find an "optimum" of benefit consisting of economic and "wellbeing" components. The following questions can be answered using E-QoL: Until which extent the construction of high standing buildings will create unbalance in social diversity and a feeling of exclusion in middle class inhabitants in a given area? Which is the limit of number of restaurants that can be attracted before generating an important shortage of parking areas? How many night clubs can be established before people start feeling that their security has been harmed?

6 This work has chosen the historical neighbourhood La Condesa located $4 \mathrm{Km}$. from the Historical Downtown Area of Mexico City as case study. Mexico City government implemented in 2000 the Bando 2 program to promote social lodging. Its implementation led to an explosion of leisure activities and business life of the central and historical neighbourhoods like La Condesa. Actions implementing the Bando 2 program have had social implications that seem to harm to "positive" perception of wellbeing by inhabitants. For example, the increase in the square metre $\left(\mathrm{m}^{2}\right)$ price, that provides economic benefits to real estate investors that do not live in the neighbourhood and that promote non-permanent lodging. "Authentic" neighbourhood life with inhabitants of different socio-economic strata is no longer possible because they cannot afford the high cost of the $\mathrm{m}^{2}$, access to parking, markets and supermarkets, and leisure activities. The emergence of franchises does not promote authentic local services and products, besides franchises can leave the neighbourhood when the economic flourishment is no longer possible or interesting. Thus, it seems that the growth of economy is not compatible with a harmonic human development, cultural benefit of the neighbourhood ${ }^{10}$.

7 This paper proposes a data science-based method used for studying QoL in the neighbourhood La Condesa. It shows how digital data can be used defining a possible Mathematical model and apply it to have a possible view of an immaterial value, like citizens' wellbeing and a multi-valuated computation of QoL index. Our approach provides a multifaceted understanding of QoL and it also considers that it can be understood as a dynamic state of the perception of inhabitants about their experience while evolving in a given urban territory, through E-QoL. The questions addressed by our study were: To which extent have urban planning and economic strategies of the neighbourhood, transformed living standards (i.e., changes in the QoL index)? Did they result in an improvement in the QoL index and inhabitants' perception of their wellbeing? Are segregation, exclusion, changes in the use of land, lack of water, overpopulation, desertification really beneficial to economy and acceptable for the area along time? To answer these research questions, we adopted a data science method for experimenting and supporting our approach for measuring QoL index of La Condesa neighbourhood. The method includes gathering data regarding different indicators associated to wellbeing and quality of life subjective perception and economic empowerment of the neighbourhood identified in existing studies. Our proposal combines datasets provided by the Mexican National Institute of Statistics and Geography that feed the Mathematical model proposed for computing the E-QoL. Given the volume of data about Mexico City we have used adapted computational methods to compute E-QoL in the neighbourhood La Condesa in Mexico City. We have applied data 
analytics techniques based on statistics and knowledge discovery to find patterns that represent the behaviour of QoL and E-QoL as social phenomenon measures.

The remainder of the paper is organized as follows. We first discuss about existing approaches devoted to the identification of variables for measuring the QoL index. Then, we give the general lines of the methodology adopted for measuring the QoL index and the E-QoL. The next section introduces our proposal of data-based QoL index and E-QoL in La Condesa, defines the measures that compose it and discusses the analytics approach proposed for computing it. The paper concludes insisting on the possibilities provided by data science techniques in addressing urban problems and discussing about future work.

\section{Modelling Quality of Life as a Mathematical Artefact}

QoL can be defined with respect to subjective and objective perspectives. Sörés and K. Pető identify two significant QoL research models, the Scandinavian emphasizing objective factors, related to resources availability and possession factors; and the American with a subjective perception ${ }^{11}$. A kind of mixture of these two approaches proposed by Erik Allardt ${ }^{12}$, based on the Maslow's model ${ }^{13}$, he created a hierarchy of needs and distinguished 3 levels: "Having, loving, being" (material-environmental and social needs and needs for personal development as well). Objective indicators include earnings, labour-market status, the availability of consumer goods and other similar material indicators. In general, Gross Domestic Products (GDP $\left.{ }^{14}\right)$ per capita and various indices, mainly those formed from economic indicators may also be considered.

Subjective wellbeing (SWB, i.e., individuals' cognitive and emotional wellbeing) has been proposed as a measure of individuals' benefits by Kahneman ${ }^{15}$. Since SWB refers to satisfaction with life, it is assumed to be relatively stable across time and to go beyond, but implicitly include, domains such as family life, work life, and leisure ${ }^{16}$. Yet, there is an increasing interest in understanding how SWB depends on context-specific factors such as, various forms of consumption, improved schools, or reduced commuting stress according to Diener and Seligman ${ }^{17}$ and Diener et al. ${ }^{18}$.

11 QoL and SWB are not interchangeable terms as they are connected to different theoretical concepts according to Stewart-Brown ${ }^{19}$. Yet, some research studies have interconnected both subjective QoL and SWB into the concept of Life Quality and Wellbeing (LQW) model ${ }^{20}$ (i.e., a kind of linear dependency). The model integrates 14 facets of subjective QoL drawn from theoretical formulations proposed by six internationally recognized QoL domains. The authors of the LQW claim that they offer a holistic model with a comprehensive conceptual coverage resulting of an experimental study that included 11 cultures "from most inhabited world regions"

\section{Quality of Life Models}

Measuring the QoL of inhabitants in urban areas has been discussed and studied by international forums and commissions ${ }^{22}$. For example, the study "How is life?" ${ }^{23}$ proposes 11 quantitative and qualitative groups of indicators (housing, income, jobs, community, education, environment, civic engagement, health, life, safety, work-life balance) that characterize wellbeing and that can be used for measuring QoL. The Human Development Index (HID) ${ }^{24}$ includes three main indicators health, education 
and living standards. The Organization for Economic Co-operation and Development (OECD) and the United Nations (UN) measure the QoL of their member countries using criteria that contribute to (i) determine whether public policies close the gap among inequalities; and (ii) to measure general progress. The European Parliament, the OECD and the World Wide Fund for Nature (WWF) have been seeking to develop indices based on accurate measurements that model daily life, poverty, inequality and the needs of the inhabitants in specific areas. The study proposed by National Statistics Institute in Spain defined a QoL index based on different studies like Eurostat which includes qualitative measures. The National Institute of Statistics (ISTAT) defined 12 indicators for evaluating progress that included economic, social and environment aspects ${ }^{25}$. The Commission on the Measurement of Economic Development and Social Progress (CMPEPS) created in 2008 in France defined new measures to evaluate social progress. This report, today called Stiglitz-Sen-Fitoussi, is a guide and basis for different QoL indices in the world ${ }^{26}$. In 2016 the Stiglitz-Sen-Fitoussi report included a new section on multidimensional analysis introducing welfare components. This measure proposed by the Quality of Life Expert Working Group includes 9 indicators (material living conditions, product or main activity, education, health, leisure and social interactions, economic and physical safety, governance and basic rights, natural and living environment, overall experience of life). Data are collected through surveys answered by individuals. Other data are gathered from the Living Conditions Survey (LCS) and the Economically Active Population Survey (EAPS). QoL indexes proposed in Hong Kong include personal, social, political, cultural, economic and environmental measures, along with 21 indicators classified into three groups: social, economic and environmental. It introduces variables such as degree of press freedom and stress.

13 In Latin America, Chile, conducts a QoL study by the Ministry of Health (MISAL). The last national poll on quality of life and health 2015-2016 (ENCAVI ${ }^{27}$ ), executed by Chili Social Studies Directorate (DESUC) was carried out to determine the status of society for the design, development and evaluation of public policies ${ }^{28}$. The project "Quality of life in Argentina" 29 proposes a ranking approach of wellbeing by department. It identifies different strategies for measuring poverty and QoL. Poverty is defined as a measure of deprivation including those who do not reach and established minimum threshold. QoL is defined with respect to an optimum economic level, where, poverty is measured with respect to a minimum value, the QoL is measured with respect to a maximum value. Then, for computing the QoL index, the study uses quantitative and qualitative indicators that are considered to model personal satisfaction. This index is defined by combining 5 categories and 20 indicators defined by socioeconomic and environmental variables. The data used for computing these measures are gathered in census, statistical sources, satellite images and surveys.

14 The Mackenzie Presbyterian University, through its Nucleus of Research in Quality of Life (NPQV) is preparing the Economic Index of Quality of Life (IEQV). This index uses other indicators besides the ones proposed by the Human Development Index (HDI) like transport, visual pollution and noise. These variables are pondered with different weights when they are combined to define the QoL index. Data used for computing these variables are collected by the Brazilian Institute of Geography and Statistics and the national survey for housing sampling. The IEQV aims to achieve a deeper analysis of the various elements that affect the evolution of human development. "The question is not to substitute any indicator (like the HDI), but to provide a broader evaluation, 
because we are building an index from a more extensive database", explains Roseli da Silva, coordinator of the Nucleus of Research on Mackenzie's Quality of Life ${ }^{30}$.

In Mexico, the welfare index named National Index of Quality of life (INCAVI) proposed by the University of Monterrey 2011 uses seven classes (health, education, personal wellbeing, good government, economy, collective life and security) of measures each divided into different qualitative and quantitative values variables ${ }^{31}$. The National Institute of Statistics and Geography (INEGI) proposed the BIARE index (self-report of wellbeing) used to measure the way people experience their own QoL. It is based on measuring the subjective indicators of wellbeing and defines the OECD guidelines.

The Paradise of Michalos ${ }^{32}$ recognises that people living in the same area can have different points of view concerning the conditions of life. Michalos ${ }^{33}$ proposes a matrix identifying (i) the paradise of the fools (ii) the real paradise (iii) the real hell and (iv) the hell of the fools. In these territories the perception of life depends on the perception of the people who live there. He underlines the importance of the conditions in which surveys are applied to gather the perception of people about their QoL. The sequence of the questions, the working area are factors that strongly influence the answers to a survey.

\section{Discussion and remarks about QoL}

17 As a result of literature analysis, we conclude that QoL can be defined as a measurable artefact with two facets as proposed by Sores and Peto ${ }^{34}$. The first facet concerns welfare that can be modelled by objective factors such as earnings, health, infrastructure, public security. The second facet concerns wellbeing that relates to subjective factors like delight, appreciation, affection. The relation of earnings and health has been widely investigated. "Research findings reveal that higher incomes lead to better health, but better health may also result in higher incomes due to increased labour productivity and more active participation in the labour market" ${ }^{35}$. This might be the reason why programs aiming to transform and improve urban territories use economy as optimization objective. Similarly, two-directional relations can be detected between education and incomes. Education enhances social participation which is a significant component of the quality of life ${ }^{36}$.

In all cases, studies are aware of the importance of considering the socio-culturaleconomic level of the population because the perception of QoL, expectations of urban actions intended to make life better are highly determined by this indicator. The inclusion of qualitative measures (e.g., happiness, mood, peace, serenity, noise, smell) can be useful to observe this perception which, as said previously, can be calibrated by the socio-economic and cultural levels. This has been shown in the projects proposed by Quercia, Schifanella y Aiello ${ }^{37}$ considering that quantitative indicators can lead to a real knowledge of the problems and needs of the inhabitants of the city. One point to explore is finding the right space to obtain the data and information that will be used to define the QoL index. Most countries work with censuses and surveys organized by public bodies and applied every 5 and 10 years directly to some inhabitants. This information may not be as representative because data are not recurrently updated, and analysis are done months and even years later. We also underline the importance of the quality of data used for computing the different variables. This quality includes 
the provenance, the choice of the population interviewed for collecting data (socioeconomic level, education, age, gender), the reliability of the data, the freshness, etc.

The use of Information and Communication Technologies (ICT) and particularly of data science techniques open new possibilities for designing different data collections methods that include explicit and implicit participation of citizens through social networks, online games, sensors and cameras. These data collection techniques complete the classic surveys and interviews applied to "representative" citizens. Data can be maintained, updated and shared with different qualities explicitly described by providers. Different analysis and models can be computed automatically and thereby enable the comparison of analysis results that can lead to more representative understanding and interpretation.

\section{Defining a quantitative model for Quality of Life: methodology} collect meaningful and objective data that can be used for computing them. For example, the United Nations Organization (UNDP) makes a report every year, which includes all its member countries, in which it measures the Human Development Index (HDI). Macroeconomic values of the country investigated introduce values on health, education and income. This organization "seeks to direct the attention of the government and civil society towards one of the most pressing challenges facing the country: achieve development with less inequality" ${ }^{42}$. The OECD conducts a study called 
How is life? This analysis considers eleven variables (objective and subjective): employment, income, housing, community, education, work balance, environment, citizen participation, health, satisfaction with life and safety. It is done with the intention that their governments direct public policies towards the problems of their population, seeking greater equality ${ }^{43}$.

The application of these models relies on data representing observations of urban territories as living entities (i.e., complex dynamic systems). To perform analytical studies of these living entities our methodology is based on the use of Technologic and Mathematical tools like urban computing proposed in the area of Information and Communications Technologies (ICT) and the emerging Data Science that proposes methods for setting data centric experiments.

\section{Data Science Techniques for Studying Urban Territories}

Having measures makes it possible to apply data science techniques for running different types of analysis starting from descriptive statistics, discovery of causal and temporal correlation among variables, discovery of urban events' patterns. Data science has opened possibilities for understanding and solving problems in the city. Proposals such as Data City, Smart City or Urban Computing and Urban Informatics are facilitating the study of inhabitants' life within urban territories and the identification and measure of variables that determine their perception and assessment of their life. First intents to use Information and Communication Technologies to address cities management problems can be explained through the notion of smart city. Cities governments implemented as public policy the use of different types of electronic data collection to supply information used to manage assets and resources efficiently to monitor and manage traffic and transportation systems, power plants, water supply networks, waste management, law enforcement, information systems, schools, libraries, hospitals, and other community services. The promise is that smart city technology allows city officials to interact directly with both community and city infrastructure and to monitor what is happening in the city and how the city is evolving. "Other terms that have been used for similar concepts include cyberville, digital city, electronic communities, flexicity, information city, intelligent city, knowledge-based city, MESH city, telecity, teletopia, ubiquitous city, wired city" ${ }^{44}$.

Urban computing is a process of data acquisitions, integration and analysis for the study and research of urban areas.

It is a process of acquisition, integration, and analysis of big and heterogeneous data generated by a diversity of sources in urban spaces, such as sensors, devices, vehicles, buildings, and human, to tackle the major issues that cities face, e.g. air pollution, increased energy consumption and traffic congestion ${ }^{45}$.

Urban computing connects unobtrusive and ubiquitous sensing technologies, advanced data management and analytics models, and novel visualization methods, to create win-win-win solutions that improve urban environment, human life quality, and city operation systems. Urban computing also helps to understand the nature of urban phenomena and even predict the future of cities $^{46}$. "The Urban Informatics Research Lab, founded in 2006, works across research and development at the intersection of people, place and technology with a focus on cities, locative media and mobile technology. Their team is transdisciplinary in that it comprises and collaborates with architects with degrees in media studies, software engineers with expertise in urban 
sociology, human-computer interaction designers with a grounding in cultural studies, and urban planners with an interest in digital media and social networking. Being hosted by the creative industries faculty, and specifically the cross-faculty research Institute for Creative Industries and Innovation enables their projects to embrace the creative energy of a range of disciplines across design, performance, production and writing" ${ }^{47}$.

\section{Principle of the methodology adopted for studying QoL}

The principle of our work is supported by the full study of Skevington that combines theory and validates the LQW approach through Mathematical analysis and explanation of the way QoL and wellbeing variables are dependent and determine each other. The challenge of measuring wellbeing is that a subjective concept determined by different factors and also by cultural and personal perspectives must be modelled and transformed into a Mathematical artefact that is, into an objective concept, namely, quality of life (QoL). It is not possible to have one unique Mathematical representation, thus, the principle of our approach considers that QoL can be modelled by different possible Mathematical models that turn different indicators into variables. Indicators are used as "sensors" that together are intended to influence a personal or collective impression of QoL and wellbeing. Transformed into variables (indicators and their associated way of computing them), indicators participate in Mathematical formulae components that combine them according to a specific strategy. The result of applying a formula to specific variables' values leads to a measure that corresponds to the QoL index. Thus, different indicators and different ways of relating them implies different facets of QoL.

As said previously, few methods have been developed first to collect the data and then transform these data that can come from polls, interviews, crowdsourcing procedures, social networks and digital sensing. Representative indexes have to be defined to transform as much as possible, reported observations and comment from citizens and city actors into abstract models that can be analysed and understood. Urban computing, urban informatics are emerging sciences willing to define such indexes. We adopt techniques stemming from urban computing and urban informatics to measure the QoL index and look for numerical arguments that can correlate QoL index to the strategies applied to activate the economy of urban territories.

This paper presents our approach for computing the index of QoL considering measures seeking to maximise a holistic hybrid return of investment modelled by the notion of elasticity of quality of life (E-QoL) that we propose. Our notion of return of investment considers both quantitative and qualitative variables calibrated to find and optimum benefit. Quantitative variables include income, employment, housing and employment whereas qualitative variables include life satisfaction, security perception, some aspects of governance and confidence to politicians' actions. Of course, qualitative aspects are translated into a combination of numerical variables to include them in the Mathematical model. Therefore, our proposal combines different data collections that feed a novel Mathematical model proposed for computing determining the elasticity of the index of QoL. We have applied data analytics computational techniques that apply Mathematical methods, statistics and knowledge discovery to find patterns within data sets that represent the behaviour of certain phenomena. 


\section{Measuring Quality of Life in La Condesa}

In Mexico City, the government has implemented programs to privilege the construction of lodging spaces in central territories (e.g., Cuauhtémoc and Benito Juárez neighbourhoods see Figure 1) instead of encouraging citizens leave to external residential areas. Mexico City government implemented ${ }^{48}$ the Bando 2 program seeking this social diversity balance. The principle was that if people decided to populate central areas again the activity of the neighbourhoods would be reactivated and consequently the QoL index of the territories would increase too. In this work we have focussed on measuring QoL in the neighbourhood La Condesa that was the one where the most changes were performed.

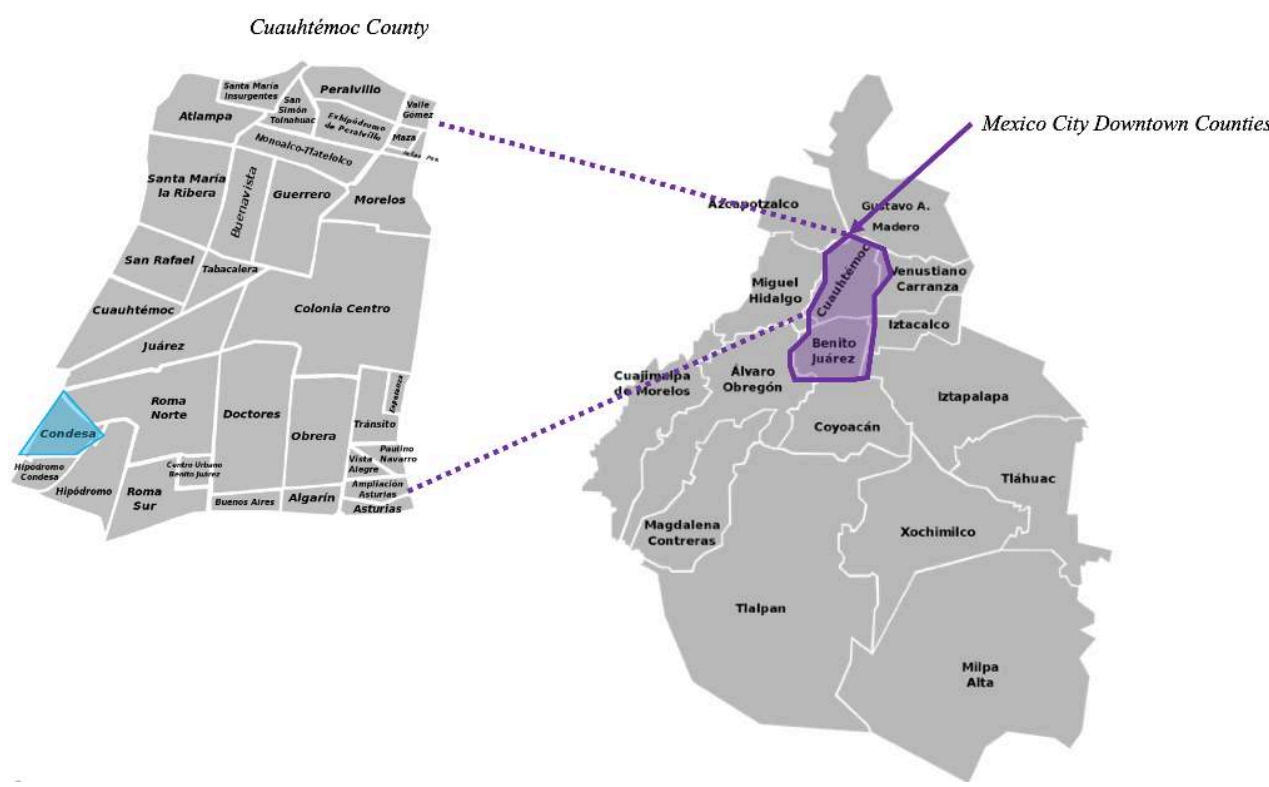

Figure 1 - Urban distribution of the Mexico City Counties \& location of La Condesa.

La Condesa $\left(19^{\circ} 24^{\prime} 45.09^{\prime \prime} \mathrm{N} 99^{\circ} 10^{\prime} 9.92^{\prime \prime} \mathrm{W}\right)$ was founded in the early years of the $\mathrm{xx}$ century in an area of 450,320.02 square meters ${ }^{49}\left(\mathrm{~m}^{2}\right)$ organized into 62 blocks where $40 \%$ of the space was initially devoted to green areas. Figure 2 shows the map of municipalities in Mexico City. The municipalities Cuauhtémoc and Benito Juárez are considered the historical downtown area of the city. The area belongs to the Cuauhtémoc Neighbourhood of Mexico City, to the south of the Zona Rosa ${ }^{50}$ and $4 \mathrm{o}$ $5 \mathrm{~km}$. from the main square, the Zocalo. La Condesa is located to the south of another important neighbourhood, La Roma, and together they form the so called, Magic Neighbourhood for Tourists because they represent the most architecturally significant area and source of the creative communities of the city. This area is in fact composed by La Condesa, Hipódromo and Hipódromo Condesa and it was founded on lands belonging to two countesses in the colonial period. La Condesa is delimited (see Figure 2) on the north/northeast by three main avenues Av. Veracruz, Av. Álvaro Obregón and Av. Yucatán; on the east by Av. de los Insurgentes Sur; on the south by Eje 4 Sur (Benjamin Franklin); and on the west/northwest by Circuito Interior (José Vasconcelos). 


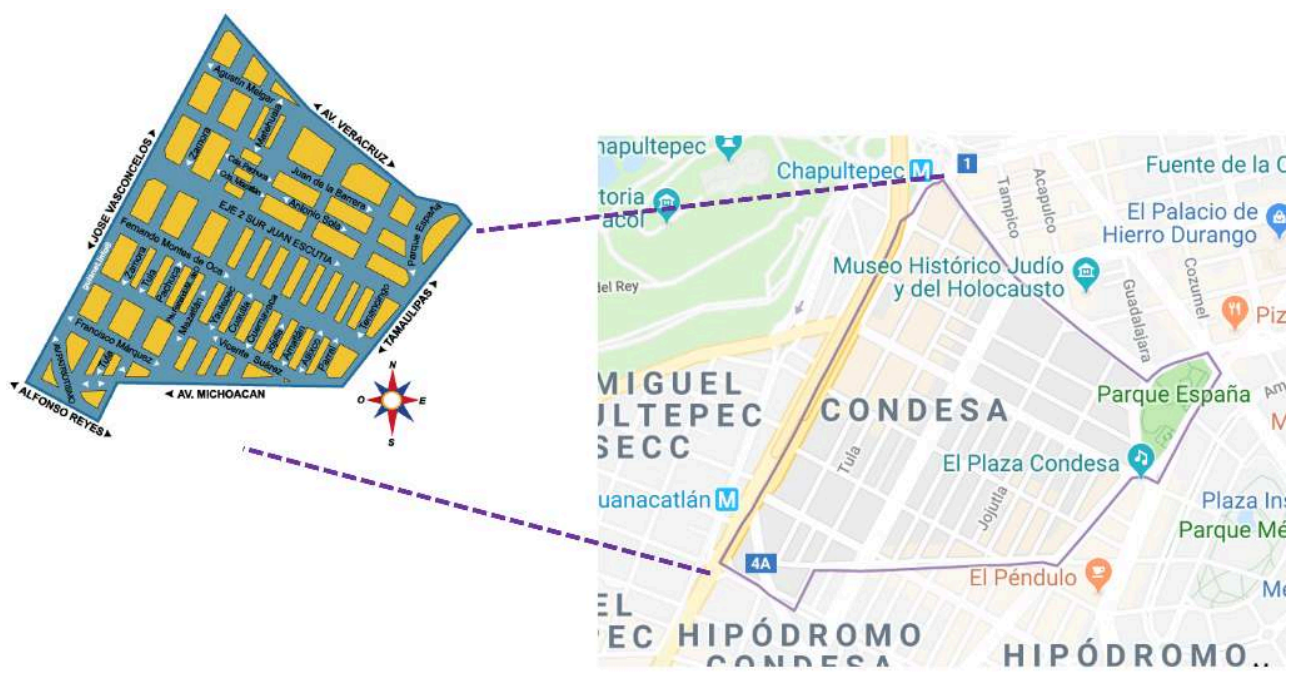

Figure 2 - Google maps geographic description of La Condesa Neighbourhood in Mexico [Google maps].

Along the decades, La Condesa has had different transformations. During the 1970s, the country's political and social effervescence led to first urban changes seeking economic activation. The government built new urban areas outside downtown for middle and upper classes. Thus, this policy caused the emigration of inhabitants from central neighbourhoods to the new promising areas in suburbs. Later, the 1985 earthquake caused the decrease of the value of properties in central neighbourhoods such as $\mathrm{La}$ Condesa. This accelerated its decline with problems such as subsidence, depopulation and wide spread of architectural, public services and social deterioration due to lack of buildings maintenance and investment.

In the early 2000's the program Bando 2 intended to activate again the neighbourhood La Condesa encouraging the construction of social lodging in the central areas of Mexico City that had been left by middle and lower classes after the Earthquake of $1985^{51}$. Activating the real estate sector, the Bando 2 program intended to encourage better living and housing conditions to citizens of different social classes. This leading action focussed on the construction of houses in the central areas of Mexico City, such as the municipalities Cuauhtémoc and Benito Juárez ${ }^{52}$. The social housing program of the Bando 2 implemented $130 \mathrm{~K}$ actions, $77 \%$ of rehabilitation and $33 \%$ of new houses. Housing policies were associated to economic actions through mortgages specifically designed for low income workers and urban actions.

As a result, many buildings dating back to the 1920's and that survived to the 1985 earthquake have become examples of Art Deco architecture, as well as innovative modern designs, which gave it an overall urban touch. In addition, a lot of new apartment buildings have been built on the sites of former original demolished houses and other infill sites. The low rents and wide spaces have attracted a new generation of young people to the area who have come to live. Companies have installed offices, with employees needing places to eat and parking facilities. This initially created a large demand for restaurants. New young inhabitants and restaurants attracted bars and nightclubs to the area.

Urban and economic transformations associated to this program seem to have activated the economy. Even if housing was the central policy of the program Bando 2, it 
was not supported by viability studies and prediction about the urban consequences of the building environment transformation ${ }^{53}$. The actions related to the Bando 2 program have been controversial regarding the respect of cultural patrimony, particularly in places where the construction of touristic and "modern" infrastructure could have damaged this patrimony and historic buildings which are destroyed rather than renovated. The actions of the program in urban areas affected the daily life of people (Cruz González, Rene, 2006) The main problem regarding the implementation of this program was that no clear building policies were stated and reinforced, which lead to the savage construction of buildings rarely devoted to social housing. This brought in negative elements such as parking problems, trash, transients, noise, crime and overload of the areas' drainage and other infrastructure. The implementation of the Bando 2 program did not produce the expected results since only $5 \%$ of the constructed living places was social housing ${ }^{54}$. A concluding remark about the program Bando 2 is that the use of the land, the economic activity and the so called "vie de quartier" in $L a$ Condesa changed dramatically. The occupation of the buildings changed from housing to commercial and administrative activities. The socio-economical level of the inhabitants that could live in the area changed too and with this started the desertification of the area. La Condesa hosted 688 commercial points in only 68 blocks. From 2000 to 2010 (INEGI) there was a decrease in the number of inhabitants from 15,916 to 11,792 . The same happened in the number of inhabited houses, with 5,350 existing housing, 4,508 were classified as habitable and the remaining 842 are classified under "other uses". All these changes caused an increase in the price of the land, which went from 21,960.00 USD in 2012 to 27,500.00 USD in 2015. Over the years, many of the buildings' uses were changed without regulation. Residents still complain of the noise, street congestion, drugs and prostitution ${ }^{55}$. They struggle to revoke permits for bars to stay open and there are demands to review the licenses of establishments which generate noise and around which crimes have happened. Another complain associated with these bars is the invasion of customers' cars into private parking spaces. Some residents claim that visibly armed guards and patrons can now be seen in the area day or night.

37 Summing up, the program Bando 2 provided benefits to real estate investors, and the few lower and middle classes citizens that could move to the area, merely received the disadvantages of the profound transformation actions of the program in the area. The side effects of the governmental program in urban territories focussing on welfare, can be described through an economic, social and politic phenomenon that redefines the "value" of central areas in cities and that causes the emigration of citizens with low income (low classes) to suburbs to privilege the arrival of citizens with middle and high income. The most prominent studies done in Mexico City for observing this phenomenon have analysed the consumption sphere to determine the behaviour of consumers of the revalued urban areas, particularly in the way new middle classes, artists, and creative millennials invest to increase their patrimony ${ }^{56}$. Delgadillo, Díaz and Salinas ${ }^{57}$ conclude that revalorized historic neighbourhoods are at the end considered elite territories. This conclusion driven thanks to a multidimensional model consisting of aspects like real state (urban property), architecture and urban rehabilitation and renovation, changes in the socio-economic strata of inhabitants, cultural, social levels (urban space/neighbourhood identity). programs have not been designed in accordance with ministries and agencies taking 
care of the environment, the protection of indigenous groups, ecology and preservation of the environment. Thus, it seems that the growth in economy that came up as side effect to the program has not been compatible with human development, with the cultural benefit of the neighbourhood. For example, valuing spaces for the benefit of the real estate investors that do not live in the areas and that promote non-permanent lodging; franchises that do not promote authentic services and products, habitability of these areas and their desertification in favour of so called, artificial empty zones.

These side effects seem to support the hypothesis that governmental actions for empowering urban territories have been empirically defined, or at least without taking into consideration all variables affecting the economy and possible side effects in the QoL of urban areas. That is, governmental programs often focus on one "optimisation objective", in most cases this objective is economic welfare. Yet, according to J. Fischer ${ }^{58}$ "in place of pondering whether policy A or policy B boosts economic growth or not, one may equally ask whether such a policy is conducive to people's health, reduces crime, raises social cohesion and increases networks, or, put simply, contributes positively to people's wellbeing".

We have observed that few statistics and quantitative studies have addressed and measured these disadvantages from the point of view of citizens daily life experience. The question is to which extent have public policies centred on real estate been adequate from the economic and social perspective? Did they result in an improvement in the QoL of inhabitants? Are segregation, exclusion, changes in land use, lack of water, over population, desertification beneficial to economy and acceptable for the area? These changes transform QoL standards. Modern urbanism promotes the balance between economic development and QoL. The current characterisation of central territories in cities and particularly in La Condesa call for an analysis of QoL measures to study the way these changes have modified the daily life of inhabitants and to which extent this balance is respected? Social and economic studies have addressed these questions partially, particularly because data providing insight is quite heterogeneous, it is collected in different moments and therefore it provides different unsynchronized snapshots of the neighbourhood as a complex dynamic system. Besides, the choice of indicators to be computed to evaluate and compare economic growth versus wellbeing of citizens, can change according to different methods of modelling wellbeing and the QoL index. We chose to use official indicators used by the Mexican Institute of Statistics and Geography (INEG ${ }^{59}$ ). We applied a classic data science workflow that includes six phases including defining the problem, gathering the data, cleaning and exploring the data, modelling the data, evaluating the model and sketching a solution to the problem.

\section{Computing Quality of Life Index for La Condesa}

The QoL index is Mathematically modelled by combining variables (i.e., indicators). The selection criteria for calculating and combining them are based on economic and political trends. We adopted the Mathematical model proposed by Stasys Puskoruis ${ }^{60}$ for measuring QoL index, based on studies by Stiglitz et al. ${ }^{11}$ We chose this model because it considers economic variables together with variables that measure health, income, quality of time at work, education, security, ethics, leisure, gender equality, etc. Thus, QoL index is given by the following formula: 
$I=\sum_{i=1}^{10} a_{i} b_{i}$

42

$b_{1}$ - health

$b_{3}$ - quality of time at work

$\mathrm{b}_{4}$ - income status

$b_{5}$ - consumption

$\mathrm{b}_{6}$ - environment and accommodation

$\mathrm{b}_{7}$ - population's education

$b_{8}$ - law, security, order and corruption levels of the population

$b_{9}$ - ethics-morality, spirituality, value of culture and leisure of the population

$b_{10}$ - population's gender equality indicator indicators are represented by $a_{i}$ terms. For instance, $b_{1}$ and the weight coefficient of that indicator $a_{1}$. The key in this formula are how to distribute weights across the indicators to calibrate the index.

The collection of information and the analysis of the data becomes essential to obtain reliable and representative results. In Mexico, the INEGI provides statistics from the national census of different years. Most of the indicators chosen for computing the QoL index were already computed for Mexico City so we filtered them for computing the QoL index for different years and first results computing E-QoL. Next, we describe the data collections.

\begin{tabular}{|c|c|c|}
\hline & Wellbeing dimension & Indicators \\
\hline 1 & $\begin{array}{l}\text { Accessibility to } \\
\text { services }\end{array}$ & $\begin{array}{l}\text { Access to health services, (1.2) houses with high speed Internet connection, (1.3) } \\
\text { houses with access to basic services }\end{array}$ \\
\hline 2 & Community & (2.1) quality of the support social network \\
\hline 3 & Education & (3.1) dropping out of school, (3.2) years in school \\
\hline 4 & Balance life - work & (4.1) satisfaction w.r.t leisure time, (4.2) people working more than 48 hours \\
\hline 5 & Income & $\begin{array}{l}\text { (5.1) gini family income per capita, (5.2) family income, (5.3) people in poverty, } \\
\text { (5.4) people in extreme poverty }\end{array}$ \\
\hline 6 & Environment & (6.1) air quality, (6.2) waste products \\
\hline 7 & $\begin{array}{l}\text { Civic compromise } \\
\text { and governance }\end{array}$ & $\begin{array}{l}\text { (7.1) civic and political participation, (7.2) electoral participation, (7.3) } \\
\text { confidence in justice/law, (7.4) perception of corruption in the juridical system, } \\
\text { (7.5) confidence on judges }\end{array}$ \\
\hline 8 & Health & $\begin{array}{l}\text { (8.1) living new born babies' expectation, (8.2) health control, (8.3) obesity rate, } \\
\text { (8.4) motherhood mortality, (8.5) children mortality, (8.6) mother deaths } / 100 \\
\text { alive new born babies }\end{array}$ \\
\hline
\end{tabular}




\begin{tabular}{|l|l|l|}
\hline 9 & Life satisfaction & $(9.1)$ idem \\
\hline 10 & Security & $\begin{array}{l}(10.1) \text { homicides rate, (10.2) confidence in police, (10.3) insecurity perception, } \\
(10.4) \text { criminal rate }\end{array}$ \\
\hline 11 & Employment & $\begin{array}{l}(11.1) \text { occupation index, (11.2) informal jobs rate, (11.3) unemployment rate, } \\
(11.4) \text { economic contribution }\end{array}$ \\
\hline 12 & Housing & $(12.1)$ rooms/person, (12.2) solid construction rate \\
\hline
\end{tabular}

Table 1 - Wellbeing indicators provided by the INEGI database. indicators are used for computing the better life index based on the notion of wellbeing and progress $^{62}$. The indicators are grouped into 12 dimensions (see Table 1): accessibility to services, community (social relations), education, balance life-work, income, environment, civic compromise and governance, health, satisfaction, security, employment, housing. Data collected for computing these indicators are a snapshot of the years 2010 - 2015. For our study, we did not use the aggregated indicators but the full data regarding the indicator required for computing the QoL index introduced in the previous section.

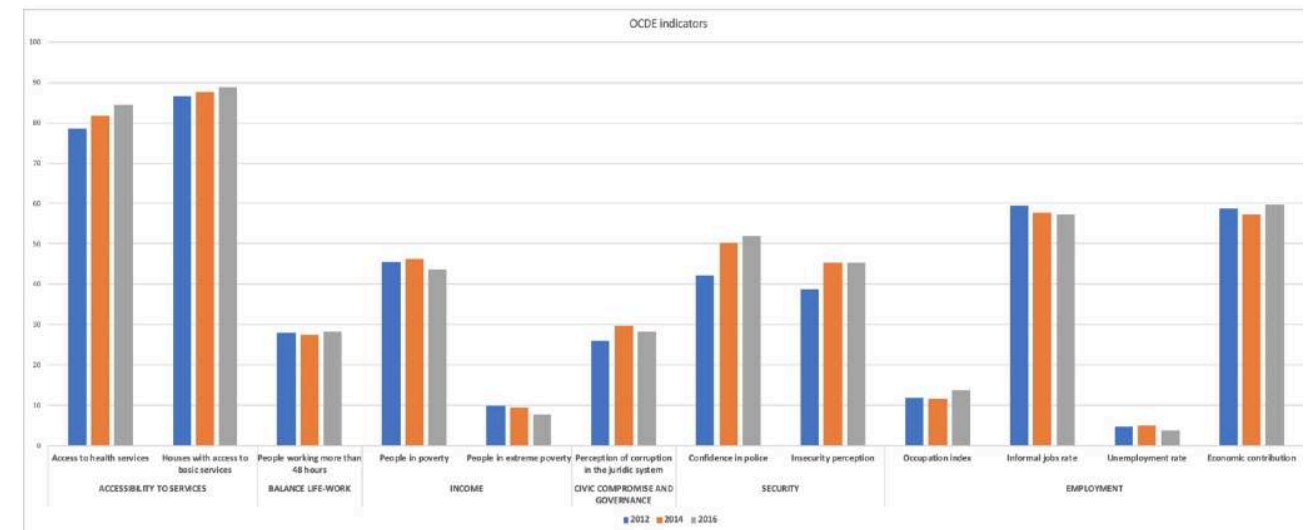

Figure 3 - General overview of the distribution of the data of the indicators.

Computing quantitative and qualitative measures. Data sets regarding QoL indicators that have been exported by the INEGI correspond to census done every two years since 2010. We remarked that not all indicators were collected in every exported data set and those of 2018 are still not available. Thus, for our experiment we first computed the QoL index in Mexico for three years 2012, 2014, 2016. After analysing the distribution of the indicators' values, we saw that some were expressed as percentages of the population that answered the census others as interval values and ad hoc measures like for the quality of air. Since we did not have the raw data for the last ones, we decided to exclude them from the computation. Therefore, we decided to use the most 
homogeneous measures in order to ensure the precision of our computations (see Figure 3).

As shown in the figure our experiment considered six dimensions namely, accessibility to services, balance life-work, income, civic compromise and governance, security and employment. For every dimension we chose those sub-dimensions that were expressed as percentages from the whole number of participants of the census. Given that these censuses are promoted by the government and are considered a civic commitment a representative amount of the population participates in this task. These data reveal already the perception of citizens of the explored indicators after the implementation of the strategies of the Bando 2 program after 5 - 10 years of its implementation. That is we can observe the side effects of the program along time after their consolidation in the urban territory as part of citizens daily lives.

According to the QoL formula that we adopted we pondered indicators according to the knowledge of the domain of our colleagues' experts in urbanism. We privileged those concerning qualitative perceptions like security and we gave less importance to those concerning economic measures. This is because our study wants to have a picture of the perception of population about their QoL in the neighbourhood La Condesa. The resulting revisited formula is given as follows:

$I=\sum_{i=1}^{12} a_{i} b_{i}$

It considers 12 measures from the chosen groups of indicators shown in Figure 3, where accessibility to services and income $\left(a_{1}, a_{2}, a_{4}, a_{5}\right)$ were pondered with 0,08 ; balance lifework $\left(a_{3}\right)$ and employment were pondered with $0,04\left(a_{9}-a_{12}\right)$; and civic compromise and governance and security with $0,16\left(a_{6}-a_{8}\right)$. The values pondered values were determined by calibrating them with experts in urbanism. Since the values were computed using programs the calibration process led to several results. The results we present here correspond to an example of the different computations that we performed. It corresponds to the one that was considered representative to the empirical (not Mathematical) observations and assessments done about the actions that modified La Condesa after the implementation of the Bando 2 program. 


\section{QUALITY OF LIFE INDEX}

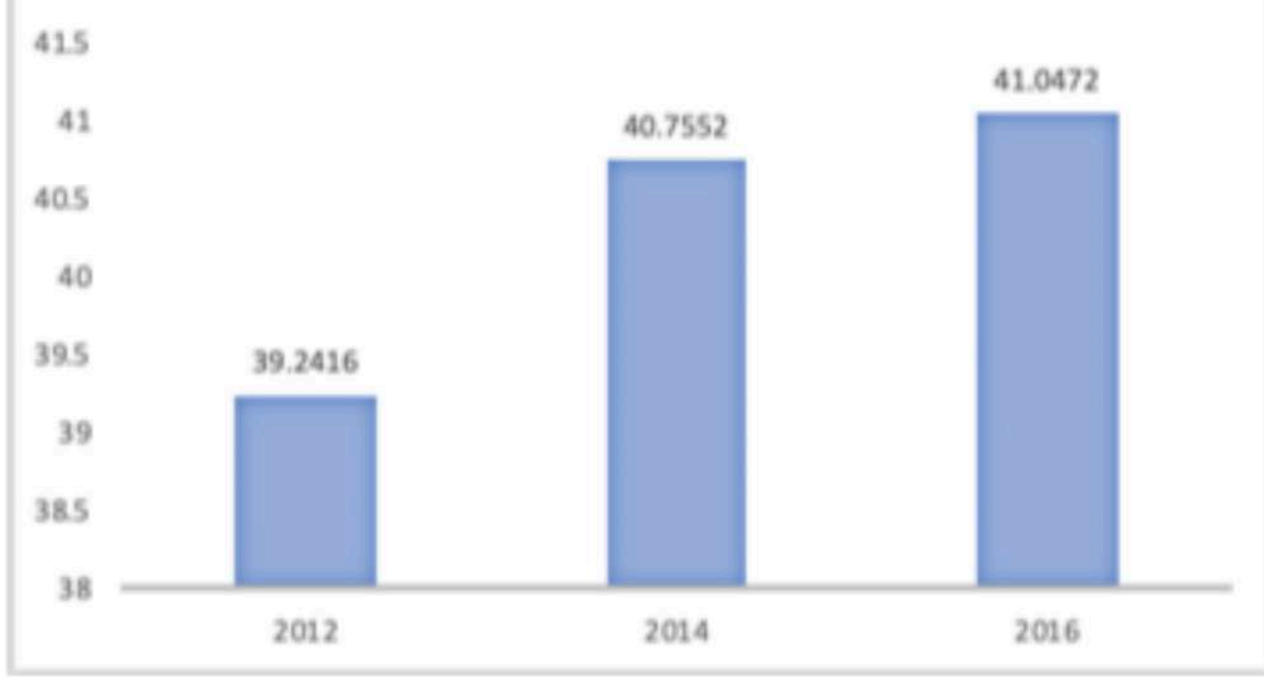

Figure 4 - Index of QoL 2012 - 2016 in La Condesa.

51 As seen in Figure 4 the QoL index shows that QoL as perceived by citizens is not very high. This means that they consider that life is acceptable but still services, security, income need public policies that can make life better. As shown in the figure QoL has become better comparing 2012 and 2016, but the increase between 2014 and 2016 was not very significant.

ur first perception through the evaluation of QoL index, validates our hypothesis that other strategies are required to measure it. Combining quantitative and qualitative indicators is a first step to provide a more representative view of QoL. Calibrating the way the different variables were pondered led to different QoL index evaluations that encouraged an holistic understanding of the index. Yet, these computations are not directly correlated with the type of actions of the Bando 2 program. We do not show how these actions are related to indicators. Our current work is devoted to study this aspect. Therefore, this will require harvesting data from social networks implicitly and through dedicated questionnaires considering long term and transient citizens, from cameras lately installed in the neighbourhood, start-ups with alternative transport means. These sources will provide input data for collecting and measuring variables regarding subjective aspects used in the literature to measure subjective wellbeing and quality of life.

We also want to use information from a project started by the Mexican INEGI willing to measure the mood of Twitter users in Mexico City. INEGI in collaboration with Twitter is making roads into data base applications to solve urban problems with technology applied to Big Data. Considering the mood of privileged citizens having access to social networks for measuring QoL index considering socioeconomic aspects can give a more representative measure. Social network users are a specific elite group, but the economic status of citizen in La Condesa are middle and upper level classes active in social networks so their voice can be representative for the type of study we are willing to perform. 
In this work, our perspective of QoL index is multi-facet and dynamic. We believe that since the different variables that can be used to compute it can change according to the evolution of urban territories configuration and economy. Thus, it can be useful to propose a Mathematical strategy to understand the relation between the change of the values of the variables and the way the QoL index changes (i.e., we want to determine their linear dependency if there is any). Therefore, we propose the concept of elasticity of QoL (E-QoL).

\section{Elasticity in Quality of Life}

We believe that together, qualitative and quantitative variables harvested under different conditions and protocols generate a more inclusive assessment of QoL by calibrating the way variables are pondered. Besides, existing Mathematical models measuring the QoL index do not consider the point of no return in this index. That is, they do not measure to which extent it is possible to have a satisfactory QoL index in a territory where specific public policies are applied.

The economic term "elasticity of demand" can be introduced into QoL index models. In Economy, elasticity is defined as the relationship between the percentage change in the quality demanded or offered and the percentage change in price.

$$
E_{p}=\frac{\Delta Q \text { uantity }}{\Delta \text { Price }}=\frac{\frac{\left(P_{1}\right)+P_{2}}{2}}{\frac{\left(Q_{1}\right)+Q_{2}}{I_{12}}}
$$

We redefine next the notion of elasticity in urbanism terms. We can see that there is a relationship between the QoL of the inhabitants in the territory with respect to the variables that effect welfare behaviour. The concept of elasticity is used in microeconomics and economic theory, introduced by Alfred R. Marshall to determine quantitatively how changes can influence another that depends on it $^{63}$. It is a measure of the degree of response of the change of one variable due to the change of another. Numerically it is given by the degree of change in a dependent variable $Y$ (i.e., the degree of change of the variable Quantity in the formula), divided by the degree of change of an independent variable $X$ (i.e., the degree of change of the variable Price in the formula). That is, the elasticity of Quantity with respect to the Price is given by the ratio between the change in Quantity divided by the change in Price.

8 We propose to revisit the notion of elasticity and apply it to urbanism, and particularly to the notion of QoL index. In urban terms, Y denotes the index of QoL in a territory, which depends on the variables that determine the urban behaviour in the territory. The principle is to compute a range of values in which the QoL index denotes wellbeing while the variables that determine it change because of the application of public policies. To which extent given public policies affect the QoL index such that it can denote or not better or worse wellbeing in citizens. This can help to observe to which extent activating night life activities can generate a feeling of insecurity in citizens walking or arriving late at night? How much noise (decibels) is acceptable before people start feeling stress?

The E-QoL can be used to provide understanding about the way the elasticity spectrum moves as a result of the implementation of governmental urban, economy and social 
planning in a given urban territory. These actions are, of course, modelled as a composition of variables (indicators) that acquire specific values when an action is implemented. These values can vary depending on the urban territory where they are observed. Thus, for a given action, the values of the qualitative and quantitative QoL that model it, can vary according to the urban territory it is implemented in. Using data science techniques, the idea is to have a meter showing its side effects in the urban territories in which actions are implemented. The meter can work continuously so it would be possible to discover some indirect side effects. That is, which aspects of QoL were expected to be touched by a specific governmental action and which were effectively touched after its implementation? Yet, it will be important to understand the conditions in which the QoL index is computed, the variables used and the conditions in which data are collected to assign values to these variables.

It is essential to first understand theoretically the range of QoL and wellbeing and the variables that affect them in a given urban territory since each urban space can be modelled by its own variables and definition of QoL. Thanks to data science techniques we can provide insight about the variables used to compute the QoL index that can adjust to different models and epistemological concepts. Therefore, we propose digital dashboard enabling the choice of variables and the definition of their Mathematical composition can let data analysts and decision makers observe the implications on elasticity when specific governmental programs and urban modifications are applied. Through the dashboard, we can for example, find the variables that define the term of QoL under the concept of the capabilities of Amartya Sen. We can even apply the notion of utilitarism ${ }^{64}$ to design the E-QoL and observe mathematically how people adjust their behaviour and perception of wellbeing while seeking the greatest happiness. Studying and understanding the rules of this adaptation phenomenon can guide the design of governmental programs. "The utilitarian can realize that, since the joint good is the sum of individual interests, the best way to promote one's interest is to promote global interest" 65 .

\section{Conclusions and Future work}

61 This paper introduced a methodology based on the use of technology and computational tools (Big Data Analytics) and data science (statistical methods and know ledge discovery) to study wellbeing and computing the QoL index considering quantitative and qualitative indicators. The interest of computing the QoL index is that it can help to design governmental programs that can revitalise urban territories and thereby empowering economy without scarifying citizens wellbeing. In the case of this research, this index has been measured in the context of the neighbourhood La Condesa in Mexico City. Some of our initial research questions could be answered with our first results. For example, to which extent have governmental programs transformed QoL index standards? It seems that the perception of QoL increased between 2012 and 2016, yet the analysed data included transient population of La Condesa. This population can have the impression of wellbeing in an area where leisure, business life and vibrant activities are promoted. Yet, real inhabitants who bear the inconvenience of this uncontrolled vibrant life, like noise, lack of parking spaces and crime, have different perception. Our current analysis needs to be refined to measure QoL in a fine-grained 
manner to see whether it is possible to exhibit different perceptions in a clearly and objective way.

A second research question stated in our work was whether segregation, exclusion, changes in the use of land, lack of water, overpopulation, desertification were really worth it to activate the economy of the area and whether this "potential" benefit was permanent along time? Since the activation of the economy of the area with the program Bando 2 was intended to empower lower classes, the numbers show that this objective was not achieved. The program empowered upper classes, since the cost of the land increased, and economically powerful investors have obtained important return of investment. Still we needed to measure the ratio between benefits and losses. Therefore, we used our results for proposing the possibility of equalising and tuning different measures to compute the E-QoL, the index proposed in this research. Therefore, we defined elasticity in urban terms establishing a relationship between the QoL index of the inhabitants in the territory with respect to the variables that effect welfare behaviour, whether positive or negative. Elasticity is introduced in the qualitative and quantitative estimation of QoL index. The result is an index that uses a range of day by day living permissible in a territory. Intuitively, we observed that E-QoL can answer to second part of our second research question, to define the balance point between benefits and losses to the activation of the economy in La Condesa. This is only possible if we include other data collections to our study, social networks with implicit and explicit data harvesting protocols, and we classify the type of population that gives an opinion (workers, investors, business people, inhabitants, transient population) using techniques for identifying communities of citizens common in data science (Leskovec et al., 2014). This input will let us fully apply E-QoL.

In this sense, studies, in our opinion must combine classic methods with the possibility of running experimental processes on top of collected data thanks to data science. Having a quantitative view of the urban, social and economic phenomena in neighbourhoods can help to discover side effects and in consequence a way of developing assessment methods of governmental programs intended to empower them.

\section{BIBLIOGRAPHY}

ALLARDT Erik (1993), “Having, loving, being: An alternative to the Swedish model of welfare research", The quality of life, 8, 88-95.

AlCARAZ Yetlaneci (2009), “Colonia Condesa: ayer y hoy...”, Ciudadanos en Red - Boletín Semanal, Mexico City.

BAtres Guadarrama Lenia (2017), "El Bando Dos y la vivienda popular vs la ciudad de lujo y la rapiña inmobiliaria", online on Sin Embargo: <https://www.sinembargo.mx/30-10-2017/3340450> (27th July 2019). 
BRONFENBRENNER Martin (1961), "Notes on the elasticity of derived demand", Oxford Economic Papers, 13(3), 254-261.

COLOMER Josep M. (1987), El utilitarismo: una teoría de la elección racional, 49, Editorial Montesinos.

Costanza Robert, Fisher Brendan, Ali Saleem, BeER Caroline, Bond Lynne, Boumans Roelof [...] SNAPP Robert (2008), “An Integrative Approach to Quality of Life Measurement, Research, and Policy", SAPIENS. Surveys and Perspectives Integrating Environment \& Society, 1(1).

CRUZ GONZÁLEZ René (2006), "Bando 2 of AMLO Sacrificed Water and Energy Supply", online on Crónica: <http://www.cronica.com.mx/notas/2006/257443.html> (18th April 2018).

Delgadillo Victor, Díaz Iván \& Salinas Luis [coord.] (2015), Perspectivas del estudio de la gentrificación en México y América Latina, México: UNAM.

DIENER Ed, SUH Eunkook (1997), “Measuring Quality of Life: Economic, Social, and Subjective Indicators", Social Indicators Research, 40.

Diener Ed, Seligman Martin Elias Pete (2004), "Beyond Money: Toward an Economy of Wellbeing”, Psychological Science in the Public Interest, 5(1).

DURAND Martine (2015), “The OECD Better Life Initiative: How's Life? and the Measurement of WellBeing", Review of Income and Wealth, 61(1), 4-17, <https://www.oecd.org/statistics/better-lifeinitiative-country-note-mexico-in-espagnol.pdf>.

FERnÁNDEZ Miranda Rodrigo \& Ruiz Rubio Rodrigo (2010), "Políticas Públicas. Beneficios Privados", online on SODEPAZ: <http://www.sodepaz.org/images/documentos/ politicas_publicas_beneficios_privados.pdf> (4th June 2019).

Fотн Marcus, CHOI Jaz Hee-Jeong, \& SATchell Christine (2011), “Urban informatics”, Proceedings of the ACM 2011 conference on Computer supported cooperative work, ACM, 1-8, <http://dx.doi.org/ 10.1145/1958824.1958826>.

GARCíA VeGA José de Jesús (2011), "Hacia un nuevo sistema de indicadores de bienestar”, Revista internacional de estadística y geografía, 2(1), 78-95, <https://www.inegi.org.mx/rde/2011/01/08/ hacia-un-nuevo-sistema-de-indicadores-de-bienestar/> (28th July 2019).

GARCía VeGA José de Jesús (2011b), “Índice de calidad de vida para México”, online on Centro de Estudios sobre Bienestar, Universidad de Monterrey (UDEM): <http://www.udem.edu.mx/> (28th July 2019).

HASSLER John, RODRÍGUez MORA José V., \& ZEIRA Joseph (2007), “Inequality and mobility”, Journal of Economic Growth, Springer 12(3), 235-259, <https://www.oecd.org/statistics/Better-Life-Initiativecountry-note-Mexico-in-Espagnol.pdf> (4th June 2018).

IMCO (2018), ¿Cómo se mide la felicidad?, online on <https://imco.org.mx/articulo_es/ como_se_mide_la_felicidad/> (2nd March 2018).

KAHNEMAN Daniel, DienER Ed, SchWARZ Norbert [Eds] (1999), Wellbeing: The Foundations of Hedonic Psychology, New York: The Russell Sage Foundation.

LeSkovec Jure, Rajaraman Anand, \& Ullman Jeff D. (2014), Mining of Massive Datasets, Cambridge: Cambridge University Press.

LóPEZ SANTILLÁn Ricardo (2007), “Lo bonito, limpio y seguro: usos del espacio de la Ciudad de México por una fracción de clase media", Alteridades, 17(34), 9-25.

MASLow Abraham, \& TURóczi Attila [trad.] (2003), A lét pszichológiája felé, Ursus Libris. 
Michalos Alex C. (2013), Essays on the Quality of Life (Social Indicators Research Series, vol. 19), Springer - Science \& Business Media.

MiLl James (1824), An Essay on Government (reprinted in Lively and Rees, 1978), 53-95.

Ministerio DE SALUd DE CHILE (2017), Encuesta de Calidad de Vida y Salud (ENCAVI), online on <http:// www.minsal.cl/wp-content/uploads/2017/02/PRESENTACION-ENCAVI-2016-11.02.2017.pdf> (4th June 2019).

PASCOE Pierce R. (2017), “Bando 2: origen de la tragedia urbana”, El Heraldo de México, <https:// heraldodemexico.com.mx/opinion/ricardo-pascoe-bando-2-origen-de-la-tragedia-urbana/> (27th July 2019).

Pueblos MÉXICO, online on <http://www.pueblosmexico.com.mx/> (18th November 2018).

PUSKORIUS Stasys (2015), “The Methodology of Calculation the Quality of Life Index”, International Journal of information and Education Technology, 5(2), 156-159, Lithuania.

PUTNAm Robert (2001), "The Prosperous Community: Social capital and public life", The American prospect, 4(13).

Quercia Daniele, Schifanella Rossano, \& Aiello Luca Maria (2014), “The Shortest Path to Happiness: Recommending Beautiful, Quiet, and Happy Routes in the City", Proceedings of the 25th ACM conference on Hypertext and social media, 116-125, <https://doi.org/10.1145/2631775.2631799>. REYES Ruiz Del CuETo Laura Alejandra (2013), Housing Access and Governance: The Case of Densification Efforts in Mexico City, 2001-2012 (B. A. Thesis), University of Texas, Austin.

ROMERo GoNZÁLEZ Joan, \& FARINós I DASí Joaquín (2006), Gobernanza territorial en España. Claroscuros de un proceso a partir del estudio de casos, Valencia: Publicaciones de la Universidad de Valencia.

SAGAR Ambuj D., \& NAJAm Adil (1998), "The human development index: a critical review”, Ecological economics, 25(3), 249-264, <http://citeseerx.ist.psu.edu/viewdoc/download? doi=10.1.1.93.7526\&rep=rep1\&type $=p d f>(4$ th June 2019).

SÁNCHEZ-Migallón Granados Sergio (2012), “Utilitarismo”, Philosophica: Enciclopedia filosófica on line, F. Fernández Labastida \& J. A. Mercado (eds), <http://www.philosophica.info/archivo/2012/ voces/utilitarismo/Utilitarismo.html>.

SECRETARÍA DE TURISMo [MeXICAN COUNCIL OF TOURISM] (2018), online on <https:// www.datatur.sectur.gob.mx/SitePages/RankingOMT.aspx> (18th November 2018).

SEN Amartya, \& NussBaum Martha C. (1998), La calidad de vida, México: Fondo de Cultura Económica.

SKEVInGTON Suzanne M., \& BöHNKE Jan R. (2018), "How is Subjective Wellbeing Related to Quality of Life? Do we Need Two Concepts and Both Measures?", Social Science \& Medicine, 206, 22-30.

SőRÉs Anett, \& PETő Károly (2015), “Measuring of Subjective Quality of Life”, Procedia Economics and Finance, 32, 809-816.

STEWART-BRown Sarah L. (2015), “Public mental health: an interdisciplinary subject?”, The British Journal of Psychiatry, 207(3), 192-4.

Stiglitz Joseph E., SEn Amartya K., \& Fitoussi Jean-Paul (2009), “The Measurement of Economic Performance and Social Progress Revisited: Reflections and Overview", online on OECD: <https:// www.oecd.org/statistics/measuring-economic-social-progress/>. 
TAMAYO Sergio (2007), Los desafíos del Bando 2. Evaluación multidimensional de las políticas habitacionales en el Distrito Federal 2000-2006, México: Edit. UACM, GDF, INVI YCAM.

TELEPORT (2019), Quality of life in Buenos Aires, online on <https://teleport.org/cities/buenos-aires/ $>$ (04th June 2019).

Wharton, University of Pennsylvania (2004), Brasil y la guerra de los índices de calidad de vida, online on <https://www.knowledgeatwharton.com.es/article/brasil-y-la-guerra-de-los-indices-decalidad-de-vida/> (4th June 2019).

Zheng Yu, CAPRA Licia, Wolfson Ouri, \& YANG Hai (2014), "Urban computing: concepts, methodologies, and applications", ACM Transactions on Intelligent Systems and Technology, 5(3), 38, <https://www.microsoft.com/en-us/research/project/urban-computing/>.

\section{NOTES}

1. "An individual's perception of [her] position in life, in the context of the culture and value systems in which [she] lives, and in relation to her goals, expectations, standards and concerns. It is a broad-ranging concept, incorporating in a complex way the person' s physical health, psychological state, level of independence, social relationships, personal beliefs, and relationship to salient features of the environment.", The World Health Organisation Quality of Life Assessment Group, WHOQOL 1994, p. 43.

2. Holistic, characterized by the belief that the parts of something are intimately interconnected and explicable only by reference to the whole (Oxford Dictionary). Holism is the idea that systems and their properties should be viewed as wholes, not just as a collection of parts.

3. Asude Malkoç (2011), "Quality of life and subjective wellbeing in undergraduate students", Procedia Social and Behavioural Sciences, 15, 2843-2847, Elsevier.

4. WHOQOL Group, 1994, cited in Skevington.

5. Costanza Robert, et al. (2008), "An integrative approach to quality of life measurement, research, and policy", SAPIENS. Surveys and Perspectives Integrating Environment and Society, 1(1).

6. Puškorius S. (2015), “The Methodology for Computing the Quality of Life Index", International Journal of Information Technology, 5(2).

7. Stiglitz J., Sen A. K., \& Fitoussi J. P. (2009), "The measurement of economic performance and social progress revisited: reflections and overview", <https://www.oecd.org/statistics/ measuring-economic-social-progress/>; "Nacional index of quality of life", <http://hdr.undp.org/ sites/default/files/HDR2016_SP_Overview_Web.pdf>, accessed the 25th February 2018; OCDE (2013), Índice para una vida mejor. Enfoque en los países de habla hispana de la OCDE. Chile, España, Estados Unidos y México, <http://www.oecd.org/centrodemexico/ Índice\%20para\%20una\%20Vida\%20Mejor\%20resumen_130529.pdf>.

8. García V. J. J. (2011), "Hacia un nuevo sistema de indicadores de bienestar", Revista internacional de estadística y geografía, 2(1), 78-95; IMCO, ¿Cómo se mide la felicidad?, <https://imco.org.mx/ articulo_es/como_se_mide_la_felicidad/>, accessed the 2nd March 2018.

9. Sen A., \& Nussbaum M. C. (1998), La calidad de vida, Fondo de Cultura Económica.

10. Fernández Miranda R. (2010), "Políticas Públicas. Beneficios Privados”, Foro de Turismo Responsable, Colección Tesis, Agencia Española para el Desarrollo, AECID, Spain, <http:// www.sodepaz.org/images/documentos/politicas_publicas_beneficios_privados.pdf>, accessed the 4 th June 2019.

11. Sőrés A., \& Pető K. (2015), “Measuring of subjective quality of life.”, Procedia Economics and Finance, 32, 809-816. 
12. Allardt E. (1993), "Having, loving, being: An alternative to the Swedish model of welfare research", The quality of life, 8, 88-95.

13. Maslow A., \& Turóczi A. (2003), A lét pszichológiája felé, Ursus Libris.

14. Gross domestic products (GDP) is a monetary measure of the market value of all the final goods and services produced in a specific time period, often annually.

15. Kahneman D. (1999), "Objective happiness", D. Kahneman, E. Diener, N. Schwarz (Eds), Wellbeing: The Foundations of Hedonic Psychology. New York : Russell Sage Foundation, 25.

16. Ibidem.

17. Diener E., Seligman M.E.P. (2004), "Beyond money: toward an economy of wellbeing", Psychological Science in the Public Interest, 5(1), 1-31.

18. Diener E., SuhE. (1997), "Measuring quality of life: economic, social, and subjective indicators", Social Indicators Research, 40, 189-216.

19. Stewart-Brown S. L. (2015), "Public Mental Health: an Interdisciplinary Subject?", British Journal of Psychiatry, 207, 192-194.

20. Skevington S. M., \& Böhnke J. R. (2018), "How is subjective wellbeing related to quality of life? Do we need two concepts and both measures?", Social Science \& Medicine, 206, 22-30.

21. Ibidem.

22. Beyond GDP was held in November 2008.

23. Durand M. (2015), "The OECD better life initiative: How's life? and the measurement of wellbeing", Review of Income and Wealth, 61(1), 4-17, <https://www.oecd.org/statistics/better-lifeinitiative-country-note-mexico-in-espagnol.pdf>.

24. Sagar A. D., \& Najam A. (1998), “The human development index: a critical review”, Ecological economics, 25(3), 249-264.

25. The National Institute of Statistics (ISTAT) defined 12 variables for evaluating progress that included economic, social and environment aspects, 5th Edition, 2017.

26. Joseph E. Stiglitz, Amartya Sen, Jean-Paul Fitoussi, Report by the Commission on the Measurement of Economic Performance and Social Progress, <https://ec.europa.eu/eurostat/documents/ 118025/118123/Fitoussi+Commission+report>, accessed the 27th July 2019.

27. Ministerio de Salud de Chile (2017), Encuesta de Calidad de Vida y Salud (ENCAVI), <http:// www.minsal.cl/wp-content/uploads/2017/02/PRESENTACION-ENCAVI-2016-11.02.2017.pdf>, accessed the 04th June 2019.

28. Ibidem.

29. <https://teleport.org/cities/buenos-aires/>.

30. <https://www.knowledgeatwharton.com.es/article/brasil-y-la-guerra-de-los-indices-decalidad-de-vida/>.

31. INCAVI (J. García Vega - 2011b) defines the following subcategories. For health (healthiness, number of visits to the doctor, fair medical service); economy (does income is enough for accessing to other basic needs besides food, accessibility to fair housing, accessibility to good job); education (academic level of schools, accessibility to good education, accessibility to cultural, sportive and leisure events); security (security in the community, victim of insecurity, capacity of police to face insecurity); good government (honesty, efficiency, quality of public services); collective life (weather, quality of the environment, quality of nongovernmental services, mobility in the city); wellbeing (availability of free time, quality of life perception, willing to spend her whole life in the community, facility to establish social interaction with family and friends).

32. Michalos A. C. (2013), Essays on the Quality of Life, 19, Springer Science \& Business Media.

33. Ibidem.

34. Sőrés A., \& Pető K. (2015), "Measuring of subjective quality of life.", Procedia Economics and Finance, 32, 809-816.

35. Ibidem. 
36. Putnam R. (1993), "The Prosperous Community: Social capital and public life”, The American prospect, 4(13), 21.

37. Quercia D., Schifanella R., \& Aiello L. M. (2014), "The shortest path to happiness: Recommending beautiful, quiet, and happy routes in the city", Proceedings of the 25th ACM conference on Hypertext and social media, 116-125.

38. "The human development concept derived from the fact that income (even if a proxy for consumption) is not a direct measure of life quality, and that other measures to do with health, education, gender equity, and so on can also be valuable" (Sen A., 1985), Commodities and Capabilities, New Delhi: Oxford University Press.

39. During the last decade, the economic growth of the real estate market and income from the activation of the tourism sector, has been achieved through the revaluation of historical downtown areas. Revaluation is the result of urban processes achieved through governmental actions aimed at bringing about changes in the territory.

40. Quercia D., Schifanella R., \& Aiello L. M. (2014), "The shortest path to happiness: Recommending beautiful, quiet, and happy routes in the city", Proceedings of the 25th ACM conference on Hypertext and social media, 116-125.

41. Sen A., \& Nussbaum M. C. (1998), La calidad de vida, Fondo de Cultura Económica.

42. Hassler J., Mora J. V. R., \& Zeira J. (2007), Inequality and mobility, Journal of Economic Growth, $12(3), 235-259$.

43. $<$ https://www.oecd.org/statistics/Better-Life-Initiative-country-note-Mexico-inEspagnol.pdf>.

44. Zheng Y., Capra L., Wolfson O., \& Yang H. (2014), "Urban computing: concepts, methodologies, and applications", ACM Transactions on Intelligent Systems and Technology (TIST), 5(3), 38 .

45. Ibidem.

46. Ibidem.

47. Foth M., Choi J. H. J., \& Satchell C. (2011), "Urban informatics", Proceedings of the ACM 2011 conference on Computer supported cooperative work, 1-8, <http://dx.doi.org/ 10.1145/1958824.1958826>.

48. Anand P. shows examples of ways in which subjective wellbeing can make a concrete contribution to policy encouraging human development issues. Anand P. "Happiness, wellbeing and human development: the case for subjective measures" (2016).

49. The measures in Mexico are given according to the metric decimal system as in most European and Latin American countries.

50. Zona Rosa is a neighbourhood in Mexico City known for its shopping, nightlife, gay community, and Korean community. It is part of the Colonia Juárez neighbourhood, located west of the historic center of Mexico City.

51. Tamayo S. (2007), Los desafíos del Bando 2. Evaluación multidimensional de las políticas habitacionales en el Distrito Federal 2000-2006, México: UACM, GDF, INVI YCAM.

52. Mexico City is divided into sixteen municipalities. Municipalities are subdivided into neighborhoods or neighbourhoods and in some parts of southern Mexico City, also into towns and rural areas, <https://en.wikipedia.org/wiki/Municipalities_of_Mexico_City>.

53. Pascoe Pierce R. (2017), "Bando 2: origen de la tragedia urbana", El Heraldo de México, <https:// heraldodemexico.com.mx/opinion/ricardo-pascoe-bando-2-origen-de-la-tragedia-urbana/>, accessed the 27th July 2019.

54. Batres Guadarrama L. (2017), "El Bando Dos y la vivienda popular vs la ciudad de lujo y la rapiña inmobiliaria", online on Sin embargo.mx: <https://www.sinembargo.mx/ 30-10-2017/3340450>, accessed the 27th July 2019.

55. Alcaraz Y. (2009), “Colonia Condesa: ayer y hoy...”, Ciudadanos en Red - Boletín Semanal, México City. Retrieved August 31, 2010. 
56. Delgadillo Victor, Díaz Ibán y Salinas Luis [coord.] (2015), Perspectivas del estudio de la gentrificación en México y América Latina, México: UNAM.

57. Ibidem.

58. Fischer Justina A. V. (2009), "Subjective Well-Being as Welfare Measure: Concepts and Methodology".

59. <https://www.inegi.org.mx/app/bienestar/>.

60. Puskorius Stasys (2015), "The methodology of calculation the quality of life index", International Journal of information Technology, 5(2), Lithuania.

61. Stiglitz J., Sen A. K., \& Fitoussi J. P. (2009), "The measurement of economic performance and social progress revisited: reflections and overview”, <https://www.oecd.org/statistics/ measuring-economic-social-progress/>.

62. "Societal progress is about improvements in the wellbeing of people and households. Assessing such progress requires looking not only at the functioning of the economic system but also at the diverse experiences and living conditions of people." The OECD framework for measuring wellbeing and progress defines a dynamic system where current wellbeing is determined by two packs of measures those concerning quality of life (health status, work life balance, education and skills, social connections, civic engagement and governance, environmental quality, personal security and subjective wellbeing) and material conditions (income and wealth, jobs and earnings, housing). These packs are sustained by the "resources of future wellbeing" like natural, economic, human and social capital. See <https://www.oecd.org/ statistics/measuring-well-being-and-progress.htm>.

63. Bronfenbrenner M. (1961), "Notes on the elasticity of derived demand", Oxford Economic Papers, 13(3), 254-261.

64. Colomer J. M. (1987), El utilitarismo: una teoría de la elección racional, 49, Editorial Montesinos.

65. Mill J. (1824), An Essay on Government (reprinted in Lively and Rees, 1978), 53-95.

\section{ABSTRACTS}

This paper presents our approach for computing an index of quality of life ${ }^{1}(\mathrm{Q} o \mathrm{~L})$ through a data science methodology considering quantitative and qualitative measures. Our methodology seeks to help to promote the maximisation of a holistic ${ }^{2}$ return of investment that we propose and name elasticity of quality of life (E-QOL). E-QoL models and calibrates variables associated to social, economic, cultural, psychological, health perspectives to find an "optimum" composite benefit including economic and "wellbeing" aspects. Our notion of return of investment expressed by the E-QoL is holistic because it considers different objective and subjective perspectives to provide a multi-facet understanding of QoL and the way it can impact the perception of citizens about their wellbeing (e.g., happiness, self-fulfilment, satisfaction). Wellbeing is an immaterial perception difficult to measure. Yet, supported by studies on the impact of quality of life on wellbeing perception, our claim is that studying measurable variables and combining them in a Mathematical model it can be possible to analyse and understand wellbeing subjective perception. Studying wellbeing subjective perception under different objective and subjective views to provide a holistic study of QoL. Thus, the model would help us to experiment and explore different perspectives of citizens' wellbeing perception and how changes in the urban environment impact it.

This work has chosen the historical neighbourhood La Condesa located $4 \mathrm{Km}$. from the Historical 
Downtown Area of Mexico City as case study where governmental programs have been designed to promote the construction of social lodging and in consequence bring inhabitants, leisure activities and business life to central territories. It seems that the growth in economy, population increase in the neighbourhood has not been compatible with citizens QoL and wellbeing perception and has not led to the increase of the quality of life index observed in the neighbourhood.

Cet article présente notre approche pour établir un indice de la qualité de vie (IQV) à l'aide d'une méthodologie de science des données qui tient compte de mesures quantitatives et qualitatives. Notre méthodologie cherche à promouvoir la maximisation d'un retour sur investissement holistique que nous proposons et que nous appelons élasticité de la qualité de vie (E-QoL). E-QoL modélise et calibre les variables associées aux perspectives sociales, économiques, culturelles, psychologiques, sanitaires pour trouver un bénéfice composite «optimal » qui inclue les aspects économiques et «bien être ». Notre notion de retour sur investissement exprimée par e-QoL est holistique parce qu'elle considère différentes perspectives objectives et subjectives pour fournir une compréhension multiforme de la qualité de vie et de la façon dont elle peut influencer la perception des citoyens de leur bien-être (par exemple, le bonheur, l'épanouissement personnel, la satisfaction). Le bien-être est une perception immatérielle difficile à mesurer. Pourtant, nous appuyant sur des études sur l'impact de la qualité de vie sur la perception du bien-être, nous avançons que l'étude de variables mesurables et leur combinaison dans un modèle mathématique permet d'analyser et comprendre la perception subjective du bien-être. Étudier la perception subjective du bien-être sous différents points de vue objectifs et subjectifs nous permet de fournir une étude holistique de la qualité de vie. Ainsi, le modèle nous aiderait à expérimenter et à explorer différentes perspectives de la perception du bien-être des citoyens et de l'impact des changements de l'environnement urbain sur celui-ci.

Ce travail a choisi comme étude de cas le quartier historique de La Condesa, situé à $4 \mathrm{~km} \mathrm{du}$ centre-ville historique de Mexico, où des programmes gouvernementaux ont été conçus pour promouvoir la construction de logements sociaux et, par conséquent, rapprocher les habitants, les activités de loisirs et la vie professionnelle des territoires centraux. Il semble que la croissance de l'économie, l'augmentation de la population dans le quartier n'a pas été compatible avec la qualité de vie et la perception du bien-être des citoyens et n'a pas conduit à l'augmentation de l'indice de qualité de vie observé dans le quartier.

Este artículo presenta nuestra propuesta para establecer un índice de calidad de vida (QQL) que tenga en cuenta las medidas cuantitativas y cualitativas, utilizando una metodología de ciencia de datos. Nuestra metodología busca promover la maximización de un retorno holístico de la inversión que proponemos y que llamamos elasticidad de calidad de vida (E-QoL). E-QoL modela y calibra las variables asociadas con las perspectivas sociales, económicas, culturales, psicológicas y de salud para encontrar un beneficio complejo «óptimo» que incluya los aspectos económicos y de «bienestar». Nuestra noción de retorno de la inversión expresada por e-QoL es holística porque considera diferentes perspectivas objetivas y subjetivas para proponer una comprensión multifacética de la calidad de vida y determinar cómo puede influir en la percepción de los ciudadanos sobre su bienestar (por ejemplo, felicidad, desarrollo personal, satisfacción). El bienestar es una percepción intangible difícil de medir. Sin embargo, con base en estudios sobre el impacto de la calidad de vida en la percepción del bienestar, sostenemos que el estudio de variables medibles y su combinación en un modelo matemático permite analizar y comprender la percepción subjetiva del bienestar. Estudiar la percepción subjetiva del bienestar desde diferentes perspectivas objetivas y subjetivas nos permite proporcionar un estudio holístico de la calidad de vida. Por lo tanto, el modelo nos ayudaría a experimentar y explorar diferentes perspectivas de la percepción del bienestar de los ciudadanos y el impacto de los cambios en el entorno urbano. 
Este trabajo eligió al barrio histórico de La Condesa, ubicado a $4 \mathrm{~km}$ del centro histórico de la Ciudad de México, para un caso de estudio. En este territorio los programas gubernamentales han sido diseñados para promover la construcción de viviendas sociales y, por lo tanto, dar acceso a los habitantes a actividades de ocio y vida profesional en regiones centrales. Parece que el crecimiento de la economía y el aumento de la población en el barrio no fueron compatibles con la calidad de vida y la percepción del bienestar de los ciudadanos y no condujeron al aumento del índice de calidad de vida observado en el barrio.

\section{INDEX}

Mots-clés: qualité de vie, élasticité, informatique urbaine, science des données

Palabras claves: calidad de vida, elasticidad, informática urbana, ciencia de datos

Keywords: quality of life, elasticity, urban computing, data science

\section{AUTHORS}

\section{GENOVEVA VARGAS SOLAR}

Université Grenoble Alpes, CNRS, Grenoble INP, LIG-LAFMIA, France

\section{ANA-SAGRARIO CASTILLO-CAMPORRO}

Universidad Nacional Autónoma de México, México 